\title{
EDUKASI HIDUP HEMAT KEPADA SISWA TAMAN KANAK- KANAK MELALUI PROGRAM PENGABDIAN MASYARAKAT
}

\author{
Nanik Linawati* \\ Program Financial and Investment, Program Studi Manajemen, Fakultas Bisnis dan Ekonomi \\ Universitas Kristen Petra, Jl. Siwalankerto 121-131, Surabaya 60236 \\ *Penulis Korespondensi: nanikl@petra.ac.id
}

\begin{abstract}
Abstrak: Setiap pribadi mengharapkan untuk senantiasa mampu mencukupi kebutuhan anggota keluarganya dalam jangka panjang sampai akhir hidupnya. Namun godaan gaya hidup konsumtif seringkali menghambat kemampuan menabung yang dalam jangka panjang berdampak pada kemampuan menyediakan dana darurat, dana pensiun, ataupun kebutuhan lain yang diperlukan di masa depan. Terkait dengan hal tersebut diperlukan edukasi "Hidup Hemat" sejak dini kepada para siswa Taman Kanak-kanak, agar kesadaran membiasakan diri untuk hidup hemat telah tertanam sejak masa anak-anak. Kegiatan Pengabdian Masyarakat memberikan kesempatan kepada para mahasiswa untuk terlibat dalam menumbuhkan kesadaran hidup hemat sejak dini kepada para siswa Taman Kanak-kanak. Tumbuhnya kesadaran hidup hemat akan menjamin kemampuan untuk menabung yang akan mampu mewujudkan kehidupan keuangan yang sejahtera dalam jangka panjang. Metoda yang digunakan melalui observasi. Implikasi kegiatan pengabdian masyarakat, yaitu menumbuhkan kesadaran kepada para siswa Taman Kanak-kanak untuk bijak membelanjakan uang.
\end{abstract}

Kata kunci: Edukasi, hidup hemat, pengabdian masyarakat, Taman Kanak-kanak

\begin{abstract}
Each person always expects to be able to meet their family needs in the long run until the end of their life. But the temptation of consumptive lifestyles often hinder the ability to save, which in the long run has an impact on the ability to provide emergency funds, pension funds, or other needs that are essential in the future. Related to this, it is necessary to educate "How to spend wisely" from an early age on Kindergarten students, so that the awareness of getting used to saving lives has been embedded since childhood. Community Service Activities (Kegiatan Pengabdian Masyarakat) provide opportunities for undergraduates to be involved in fostering awareness of life-saving from an early age to kindergarten students the growth of life-saving awareness will guarantee the ability to save money that will be able to create a prosperous financial life in the long run. The method used is observation. The implication of community service activities is to raise awareness for Kindergarten students to spend their money wisely.
\end{abstract}

Keywords: Education, life-saving, community service, kindergarten.

\section{PENDAHULUAN}

Masyarakat di abad digital sangat mendambakan experience dalam segala aspek kehidupannya, baik pada saat berbelanja, berwisata, ataupun saat menikmati proses mengkonsumsi jasa tertentu. Penekanan pada keinginan mendapatkan experience merupakan perangkap bagi masyarakat untuk lebih mengutamakan keinginan daripada kebutuhan, karena keinginan ibarat luasan cakrawala yang tidak bertepi. Sementara setiap manusia memiliki pendapatan yang terbatas. Apalagi pada era digital saat ini sebagian masyarakat yang memiliki pekerjaan atau menjalankan bisnis dengan menggunakan aplikasi online memperoleh pendapatan yang bervariasi setiap hari.
Memperhatikan pola pendapatan yang cenderung bervariasi seharusnya mendorong masyarakat bersikap bijak dalam mengelola keuangan keluarga. Ketidak-pastian perolehan pendapatan harus disikapi dengan melakukan cost-reducing pada pengeluaran sehari-hari. Keberhasilan setiap keluarga untuk melakukan cost-reducing sangatlah tergantung pada cara menyikapi uang yang dimiliki. Keluarga yang menyikapi uang yang dimiliki sebagai dana untuk kebutuhan jangka panjang akan lebih terdorong untuk memiliki pola hidup hemat. Namun keluarga yang meyakini bahwa uang yang dimiliki bulan ini merupakan sumber dana untuk bulan ini saja akan cenderung untuk segera membelanjakan semua uang yang dimiliki, sehingga tipe keluarga seperti ini tidak 
memiliki tabungan yang cukup untuk keadaan darurat maupun untuk memenuhi pengeluaran di masa depan termasuk kebutuhan dana pensiun. Kondisi yang mengkawatirkan seperti ini harus dicarikan solusi, agar masyarakat memiliki mindset yang benar dalam mengelola setiap rupiah yang dimiliki.

Universitas Kristen Petra melalui Program Pengabdian Masyarakat yang diintegrasikan dengan mata kuliah Keuangan Personal, yang merupakan bagian dari kurikulum Program Manajemen Keuangan Program Studi Manajemen Fakultas Bisnis dan Keuangan merancang program edukasi "Hidup Hemat" bagi para siswa Taman Kanak-kanak (TK). Tema yang diambil "Anak Bijak Hidup Hemat". Kami berkeyakinan bahwa mengajak masyarakat kembali untuk hidup hemat bukanlah hal yang mustahil, seperti ada pepatah bahasa Indonesia menyatakan "alah bisa karena biasa", yang berarti apabila suatu pekerjaan telah terbiasa dilakukan, maka tidak akan terasa sukar.

Penjabaran tema "Anak Bijak Hidup Hemat" disajikan melalui tutorial yang dibawakan oleh mahasiswa peserta program Pengabdian Masyarakat dengan bantuan media ajar, serta disampaikan melalui sejumlah permainan dan kegiatan interaktif yang menyenangkan. Pendekatan Learn and Play digunakan untuk menyampaikan materi "Anak Bijak Hidup Hemat". Penyajian materi tutorial "Anak Bijak Hidup Hemat" menggunakan media Flip Chart dan boneka peraga "Needs or Wants". Sedangkan serangkaian aktivitas yang diharapkan mampu menstimuli para siswa Taman Kanak-kanak untuk memiliki keinginan yang kuat untuk berhemat, meliputi permainan kartu kembar "Hidup Hemat", permainan kartu domino "Hidup Hemat", puzzle huruf "Anak Bijak Hidup Hemat, Puzzle gambar yang menampilkan salah satu contoh praktis cara hidup hemat dan mewarnai gambar "Hidup Hemat".

\section{METODE PELAKSANAAN}

Metode yang diterapkan yaitu dosen memberikan wawasan dan pelatihan sebelum mahasiswa terlibat dalam program Pengabdian Masyarakat pada mata kuliah Keuangan Personal di wilayah Surabaya. Pada kunjungan pertama ke Taman Kanak-kanak yang telah menerima proposal, mahasiswa akan mengumpulkan informasi terkait jumlah siswa dan karakteristik siswa. Observasi yang dilakukan mahasiswa akan memberikan perspektif menyeluruh terkait obyek yang diamati (Holloway, 2002). Tujuan melakukan observasi, yaitu mencari informasi tentang kegiatan Peng- abdian Masyarakat yang diperlukan para siswa Taman-Kanak-kanak. Setelah para mahasiswa memperoleh gambaran kebutuhan para siswa Taman Kanak-kanak, ragam aktivitas Abdimas dirapatkan oleh para mahasiswa, kemudian diputuskan aktivitas yang akan dilakukan. Para mahasiswa selanjutnya membeli segala keperluan untuk menunjang aktivitas yang telah diputuskan. Kemudian, bahan-bahan yang telah dibeli untuk membuat media ajar dan permainan dipersiapkan dengan seksama.

Tahapan berikutnya, yaitu melaksanakan satu demi satu aktivitas Abdimas yang telah dipilih dengan persiapan yang matang. Selama kegiatan berlangsung, para mahasiswa melakukan pengamatan, mendokumentasikan dalam bentuk foto maupun video. Setelah melaksanakan aktivitas Abdimas tertentu, para mahasiswa meminta guru Taman Kanak-kanak yang terlibat dalam aktivitas untuk mengisi angket evaluasi kegiatan.

Anggota tim dosen akan datang dalam salah satu pertemuan untuk melakukan evaluasi kinerja para mahasiswa, sambil menilai efektivitas kegiatan Abdimas dan mencari informasi dari para guru dan kepala sekolah terkait kebutuhan pengembangan program Abdimas untuk angkatan berikutnya. Berdasarkan data dan informasi yang diperoleh mahasiswa, kemudian para mahasiswa menganalisa efektivitas setiap aktivitas yang dilakukan, mengevaluasi, dan memberikan rekomendasi melalui laporan yang dibuat. Berdasarkan laporan mahasiswa dan dilengkapi hasil pengamatan di lapangan selama melakukan kunjungan ke lokasi Taman Kanak-kanak, penulis menyajikan dalam artikel ini.

\section{HASIL DAN PEMBAHASAN}

Program Pengabdian Masyarakat dilaksanakan oleh mahasiswa Program Manajemen Keuangan Fakultas Bisnis dan Ekonomi Universitas Kristen Petra Surabaya. Jumlah personil yang terlibat sebanyak 76 mahasiswa dan 4 dosen pendamping, yang berasal dari dua kelas peserta mata kuliah Keuangan Personal. Seluruh mahasiswa peserta kegiatan Pengabdian Masyarakat dibagi menjadi 16 kelompok, dimana per kelompok ratarata beranggotakan 5 orang mahasiswa. Kegiatan Pengabdian Masyarakat melibatkan 16 Taman Kanak-kanak Mitra yang ada di Surabaya. Pelaksanaan Pengabdian Masyarakat berlangsung dalam bulan April sampai Mei 2019. Jumlah siswa Taman Kanak-kanak yang dilayani sebanyak 586 anak dan melibatkan 72 guru Taman Kanakkanak. Rincian Taman Kanak-kanak Mitra tersaji pada Tabel 1. 
Tabel 1. Taman Kanak-kanak Mitra Kegiatan Pengabdian Masyarakat Tahun 2019

\begin{tabular}{clcc}
\hline No. & $\begin{array}{c}\text { Nama Taman Kanak- } \\
\text { kanak }\end{array}$ & $\begin{array}{c}\text { Jumlah } \\
\text { Siswa }\end{array}$ & $\begin{array}{c}\text { Jumlah } \\
\text { Guru }\end{array}$ \\
\hline 1 & TK. Kyai Ibrahim II & 58 & 4 \\
2 & TK. Bina Nurani & 27 & 3 \\
3 & TK. Yasporbi & 60 & 4 \\
4 & TK. Yalista & 123 & 10 \\
5 & TK. Eleos & 16 & 4 \\
6 & TK. St. Caecilia & 35 & 5 \\
7 & TK. Karya Widya & 31 & 2 \\
8 & TK. Baptis pengharapan & 30 & 3 \\
9 & TK. Kartini- J. Kutisari & 20 & 3 \\
10 & TK. Bethel Sulung & 16 & 2 \\
11 & TK. St. Helena & 62 & 10 \\
12 & TK. Kartini- J. Genteng & 18 & 3 \\
13 & TK. Mawar & 28 & 6 \\
14 & TK. Hati Bunda & 22 & 5 \\
15 & TK. Rainbow Kiddy & 17 & 6 \\
16 & TK. Sekar Melati & 23 & 2 \\
\hline & Total & $\mathbf{5 8 6}$ & $\mathbf{7 2}$ \\
\hline
\end{tabular}

\section{Materi Ajar}

\section{Hemat Belanja}

Penghematan uang belanja dapat dilakukan jika keluarga menggunakan produk yang dibeli dalam jumlah yang wajar. Penggunaan produk secara belebih akan berakibat keluarga akan berbelanja lebih sering, sehingga jumlah uang yang dibelanjakan menjadi lebih banyak. Pengendalian pemakaian produk pada jumlah yang wajar akan membantu keluarga untuk menghemat uang belanja yang dapat dilakukan melalui sikap makan secukupnya, mengambil pasta gigi secukupnya, menggunakan sabun mandi secukupnya, serta merawat pakaian dengan baik, agar tidak cepat rusak ataupun kotor.

2. Hemat Dana

Dana yang dimiliki setiap keluarga terbatas, oleh karena itu harus dikelola dengan bijak. Dana milik keluarga dapat dihemat jika setiap anggota keluarga memiliki prinsip yang tepat terhadap pengelolaan uang, yang dapat dicapai melalui sikap membeli berdasarkan kebutuhan, membatasi frekuensi jajan, membantu mengasuh adik, agar tidak perlu menyewa pengasuh, belajar bersama teman, agar tidak perlu membayar biaya les pelajaran sekolah.

3. Hemat Energi

Pengeluaran uang orangtua dapat dihemat, jika semua anggota keluarga hemat energi dengan cara: memadamkan televisi saat tidak ditonton, memadamkan lampu saat meninggalkan ruangan, mematikan peralatan listrik saat tidak diperlukan, dan mematikan keran air saat tidak diperlukan.

\section{Hemat Harta}

Anak-anak tidak perlu menambah pengeluaran orangtua jika bersikap hemat terhadap barangbarang miliknya, dengan cara: mengembalikan mainan ke wadahnya, merawat kendaraan miliknya, misalkan sepeda anak, membantu orangtua untuk menyiram tanaman dan memberi makan hewan peliharaan.

\section{Hemat Kesehatan}

Kesehatan merupakan anugerah dari Tuhan yang sangat berharga. Anak-anak dapat tetap sehat jika secara teratur tidur pada saat jam istirahat, mandi secara teratur, selalu mencuci tangan sebelum makan, dan menggunakan payung atau jas hujan saat beraktivitas di musim hujan.

6. Hemat Perasaan

Hemat dapat dipersamakan dengan menjaga. Selain menjaga kesehatan dan harta milik, anak-anak perlu belajar menjaga perasaan orangtua, teman, atau orang lain, dengan cara: membantu ibu, berbagi dan menolong teman, rukun dengan teman, seta berperilaku baik di sekolah.

\section{Teknik Penyampaian}

\section{Flip Chart}

Siswa Taman Kanak-kanak (TK) memerlukan contoh konkrit sehari-hari untuk memahami praktik-praktik hidup hemat. Cara untuk mengkomunikasikan hidup hemat kepada para siswa TK dapat disampaikan melalui media gambar praktik hidup hemat, yang dikategorikan ke dalam enam kelompok.

1. Hemat Energi, yang terdiri dari mematikan lampu saat tidak digunakan, mematikan televisi setelah menonton, mematikan tombol alat elektronik saat tidak diperlukan, dan mematikan keran air saat tidak diperlukan.

2. Hemat Harta, yang terdiri dari merawat mainan, menyiram tanaman, memberi makan hewan peliharaan, memelihara perabot yang digunakan.

3. Hemat Kesehatan, yang terdiri dari berpayung saat hujan, mandi teratur, tidur pada waktunya, dan mencuci tangan sebelum makan.

4. Hemat Dana, yang terdiri dari membantu mengasuh adik, belajar bersama, mengurangi jajan, dan membeli sesuai keperluan

5. Hemat Belanja, yang terdiri dari mengambil makanan secukupnya, mengambil pasta gigi secukupnya, menggunakan sabun mandi secukupnya, dan merawat pakaian.

6. Hemat Perasaan, yang terdiri dari membantu ibu, belajar sungguh-sungguh, menolong sesama, dan bermain bersama teman. 
Bahan Flip Chart terbuat dari kertas poster berukuran A3 yang dicetak gambar contoh praktik hidup hemat. Jumlah contoh hidup hemat sebanyak 24 gambar yang telah disusun berdasarkan enam kategori hidup hemat. Seluruh gambargambar dijilid dengan ring kawat agar mudah untuk dibalik saat memeragakan di depan para siswa TK.

Pada saat menjelaskan setiap contoh hidup hemat, para mahasiswa menyampaikan pentingnya berperilaku hidup hemat dengan intonasi suara yang meyakinkan disertai dialog bersama para sisiwa TK, apakah mereka sudah melakukan tindakan tersebut. Jika para siswa TK sudah melakukannya, maka mahasiswa yang sedang memeragakan gambar hidup hemat akan memberi pujian kepada para siswa TK.

Pelaksanaan peragaan praktik hidup hemat berlangsung dengan meriah, karena para siswa TK merasa bangga, saat mendapat pujian dari para mahasiswa. Para siswa TK penasaran menunggu peragaan gambar berikutnya, untuk memastikan bahwa mereka sudah berperilaku hemat untuk contoh praktik hidup hemat yang lain.

Di sisi lain, para mahasiswa juga tersadarkan pada saat mempersiapkan diri sebelum mengajar. Jika ada beberapa aktivitas, mahasiswa tidak melakukannya, maka materi praktik hidup hemat mengingatkan kembali akan pentingnya hidup hemat untuk mengendalikan pengeluaran uang belanja, agar uang yang dimiliki masih dapat disisihkan untuk ditabung bagi masa depan.

Kegiatan tutorial hidup hemat ditunjang dengan aktivitas bermain kartu kembar "Hidup Hemat", kartu domino "Hidup Hemat", puzzle huruf "Anak Bijak Hidup Hemat, Puzzle gambar yang menampilkan contoh praktis cara hidup hemat dan mewarnai gambar "Hidup Hemat".

Bedasarkan hasil isian angket yang diisi oleh para guru Taman-Kanak-kanak, rata-rata jawaban menyatakan setuju bahwa tutorial praktik Hidup Hemat yang ditunjang dengan kegiatan permainan dan aktivitas mewarnai gambar contoh praktik Hidup Hemat mampu menumbuhkan kesadaran para siswa Taman Kanak-kanak untuk hidup hemat.

\section{Panggung Boneka “Needs or Wants}

Pesan hidup hemat difasilitasi dengan peragaan panggung boneka "Needs or Wants". Jumlah boneka peraga sebanyak enam buah. Tiga boneka buah mewakili Needs (kebutuhan) yang terdiri dari pepaya, stroberi, dan pisang. Sementara, tiga boneka junk food mewakili wants (keinginan) yang terdiri dari pizza, ice cream, dan donat. Alur cerita disusun dengan menyajikan komparasi antara tokoh-tokoh needs dan wants. Tokoh-tokoh wants memamerkan bahwa mereka adalah makanan favorit anak-anak. Mereka selalu menjadi idola anak-anak, selalu dirindukan anak-anak, dan selalu ada di benak anak-anak.

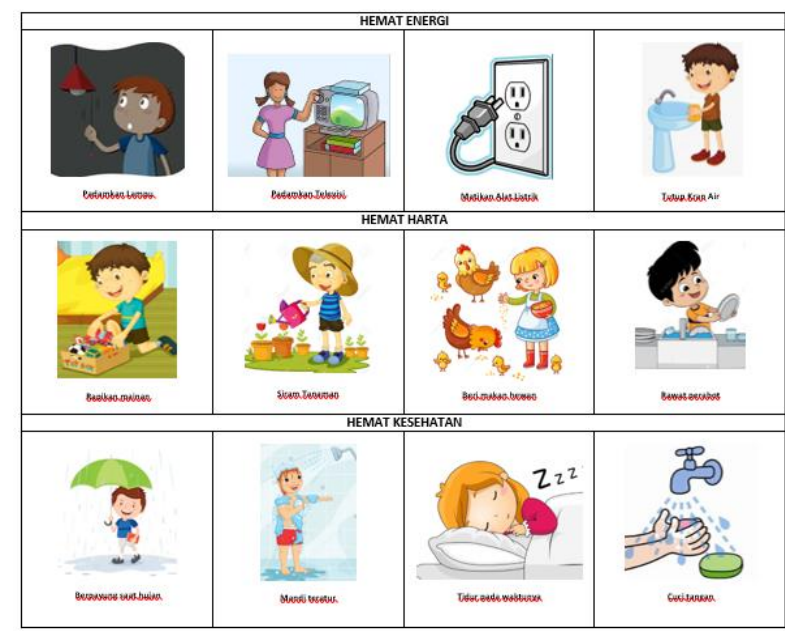

Gambar 1. Penerapan Hidup Hemat

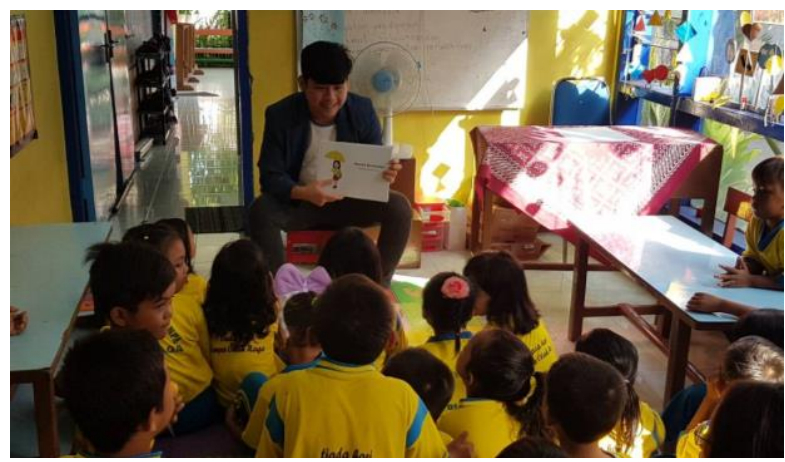

Gambar 2. Flip Chart Hidup Hemat

Sementara tokoh-tokoh needs berusaha meyakinkan bahwa yang lebih penting adalah manfaat makanan bagi kesehatan anak-anak. Selain itu buah-buahan berharga murah, sehingga akan menolong orangtua untuk dapat menabung untuk masa depan anak dan keluarga. Akhirnya pertentangan antara dua kelompok makanan ditengahi oleh seorang mahasiswa yang menyampaikan bahwa junk food memang disukai anak-anak, namun para siswa TK selayaknya jangan makan terlalu sering, karena kurang baik untuk kesehatan dan mengakibatkan pengeluaran belanja keluarga menjadi lebih besar.

Sang mahasiswa memotivasi para siswa TK untuk teratur makan buah, karena buah akan meningkatkan daya tahan tubuh terhadap serangan penyakit. Selain itu, harga buah murah, sehingga orangtua akan memiliki cukup uang untuk disisihkan dan ditabung untuk masa depan.

Para siswa TK mengikuti penayangan panggung boneka Needs or Wants dengan antusias. Siswa yang sudah terbiasa memakan buah akan menunjuk salah satu buah kesukaannya, seperti 
pisang. Sementara yang lebih suka makan junk food akan dengan semangat mendukung makanan idolanya, yaitu donat dan ice cream. Setelah para siswa TK menyampaikan responnya. Mahasiswa kembali menegaskan agar para siswa TK dianjurkan setiap hari makan buah, karena sehat dan hemat. Sementara junk food boleh dimakan, tetapi jarang-jarang saja.

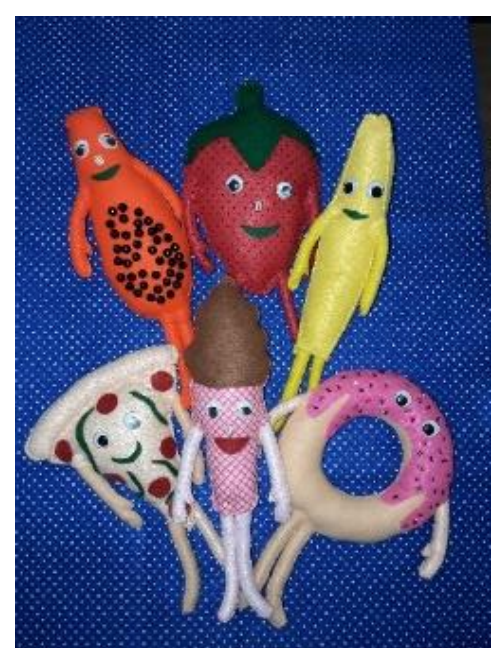

Gambar 3. Boneka Needs or Wants

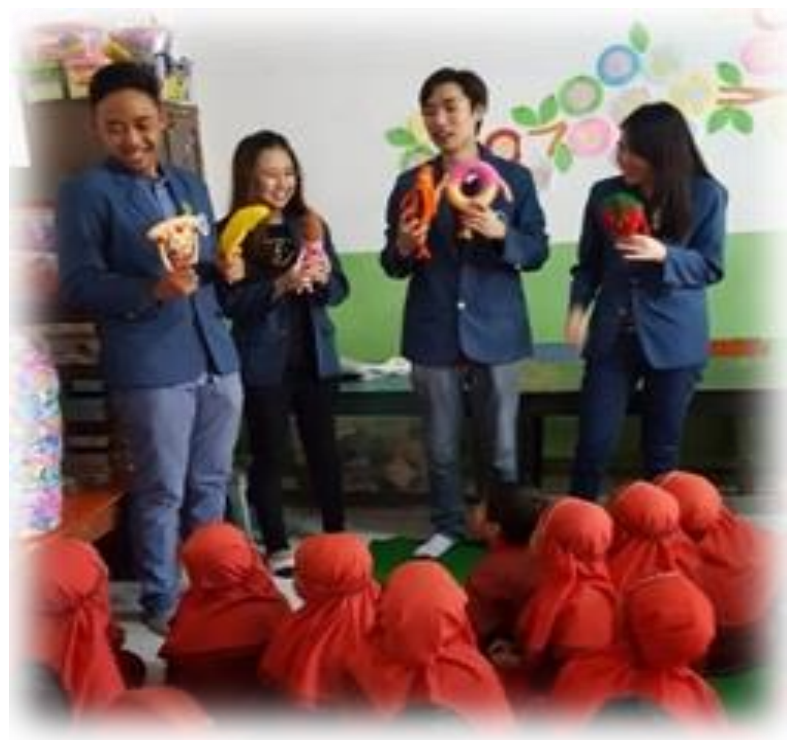

Gambar 4. Panggung Boneka "Needs or Wants"

Hasil angket yang diisi oleh para guru Taman Kanak-kanak, rata-rata setuju bahwa pertunjukan panggung boneka "Needs or Wants" dapat menggugah kesadaran para siswa Taman Kanak-kanak untuk mengutamakan kebutuhan dari pada keinginan dalam menggunakan uang sakunya.

\section{Permainan kartu kembar "Hidup Hemat"}

Kartu kembar memiliki daya tarik bagi para siswa TK, karena tersimpan nuansa surprise. Para siswa TK akan merasa senang manakala pasangan- pasangan kartu yang diletakkan dalam posisi terbalik, kemudian berhasil ditebak. Siswa TK merasa senang saat dua kartu yang mereka buka memiliki gambar yang sama, mereka merasa bangga pada kemampuannya untuk menebak gambar yang sama. Sementara siswa TK yang belum berhasil untuk menebak dengan tepat akan berusaha mengingat posisi setiap variasi gambar yang ada, agar pada saat gilirannya tiba ia dapat menebak dengan tepat.

Pesan "Hidup Hemat" dititipkan pada seluruh gambar yang tersedia. Sementara, cara yang ditempuh untuk menanamkan pesan "Hidup Hemat" dilakukan dengan mewajibkan siswa TK yang berhasil menemukan gambar yang sama untuk menyebutkan gambar yang tertera pada kartu, misal: membantu ibu. Kewajiban menyebutkan gambar pada kartu akan memperkuat ingatan para siswa TK terhadap praktik-praktik hidup hemat, yang selanjutnya akan memotivasi siswa TK untuk melakukannya dalam kehidupan seharihari.

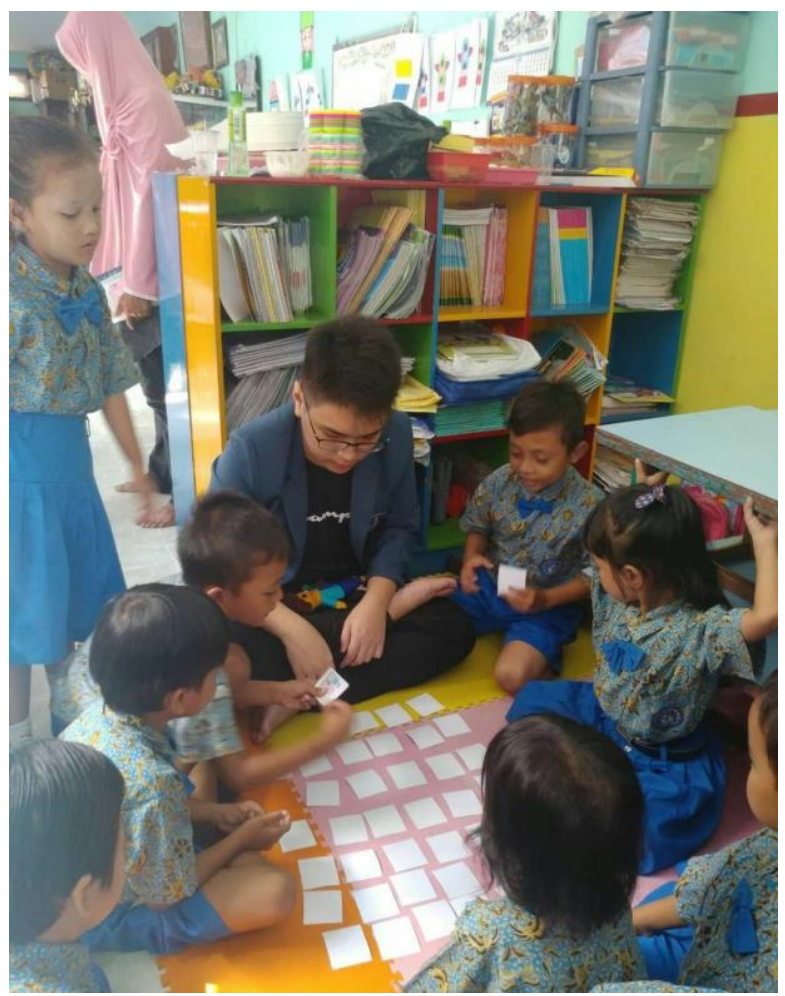

Gambar 5. Kartu domino "Hidup Hemat"

Kartu domino "Hidup Hemat" memiliki daya tarik bagi para siswa TK, karena didalamnya menantang siswa untuk cermat mencocokkan gambar kartu yang ada di meja dengan koleksi gambar pada kartu domino yang dipegangnya. Siswa TK akan merasa senang jika memiliki gambar yang cocok dengan gambar kartu yang ada di meja. Siswa yang berhasil menyerahkan seluruh kartu dominonya lebih dulu, dialah pemenangnya. 
Pesan "Hidup Hemat" dititipkan dengan cara mewajibkan setiap siswa untuk menyebutkan gambar yang tertera di kartu, pada saat kartu domino yang diserahkannya sama dengan gambar kartu domino yang di meja, misal: gambar tidur pada waktunya.

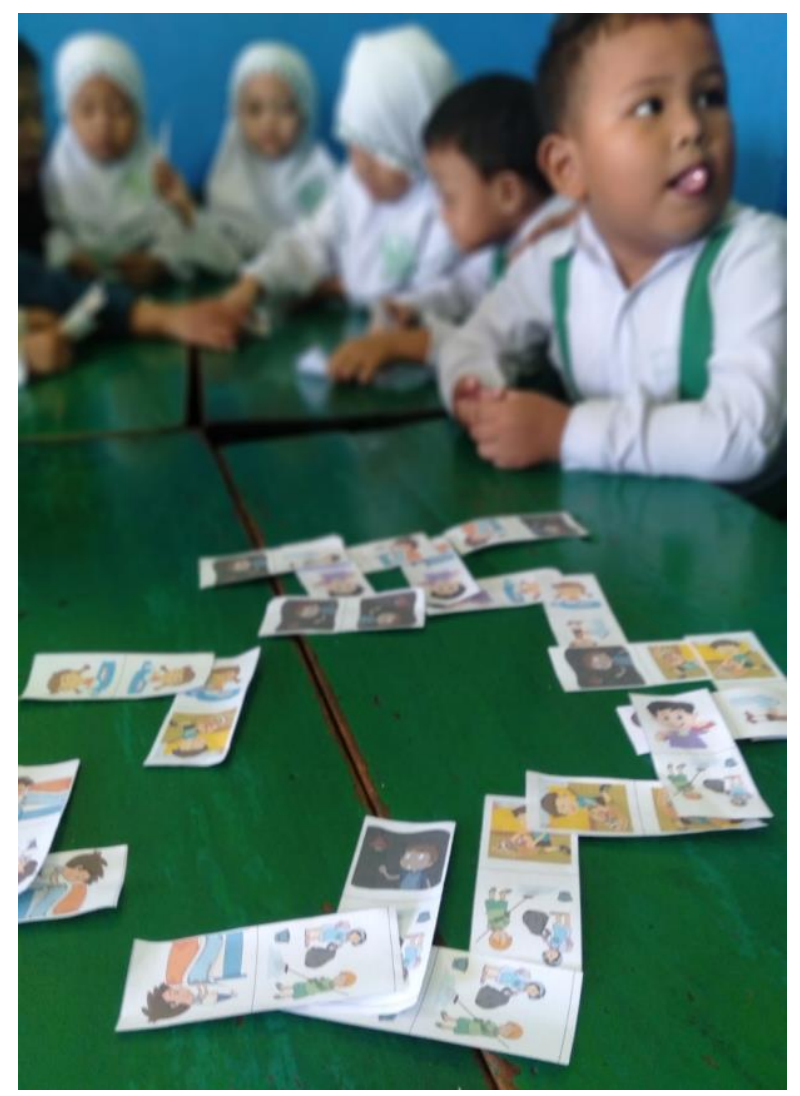

Gambar 6. Puzzle huruf "Hidup Hemat"

Hasil isian angket yang diisi oleh para guru Taman-Kanak-kanak, rata-rata jawaban menyatakan setuju bahwa Permainan Kartu Kembar Hidup Hemat mampu meningkatkan daya ingat para siswa Taman Kanak-kanak untuk menghafal praktik-praktik hidup hemat.

\section{Permainan Puzzle Huruf}

Kurikulum TK mengakomodir kemampuan para siswa TK untuk mulai mengenal huruf alphabet dan berusaha merangkai menjadi kata dan frasa dalam jumlah terbatas. Program pengabdian masyarakat dengan tema "Hidup Hemat" berusaha mengintegrasikan pesan "Hidup Hemat" dengan aktivitas mengeja huruf dan merangkainya menjadi kata dan frasa.

Frasa yang wajib disusun setiap kelompok siswa TK adalah "anak bijak hidup hemat". Semua huruf yang dipersiapkan merupakan huruf kecil, karena para siswa TK hanya mengenal huruf kecil. Selain itu font yang dipilih harus font standar, agar bentuk huruf mudah dikenali oleh setiap siswa TK.
Cara bermain dilakukan dengan membagikan sekelompok huruf warna-warni yang akan membentuk frasa "anak bijak hidup hemat". Hurufhuruf dikemas dalam kantung plastik, kemudian dibagikan kepada setiap siswa TK. Langkah pertama, para mahasiswa akan memperagakan sebuah poster yang bertuliskan "anak bijak hidup hemat". Langkah kedua, salah satu mahasiswa akan memandu cara membaca setiap huruf dan merangkainya menjadi kata dan kemudian frasa.

Jika semua siswa TK sudah mampu membaca frasa "anak bijak hidup hemat", maka langkah ketiga, para siswa TK akan diberi aba-aba oleh mahasiswa terkait saat kapan diijinkan untuk mulai menyusun huruf menjadi frasa yang telah diperagakan. Siswa yang telah berhasil menyusun frasa "anak bijak hidup hemat" dengan tepat akan diberi snack.

Pada saat bermain, setiap siswa TK melakukan penyusunan huruf dengan semangat. Mereka ingin menunjukkan kemampuannya untuk mengenal huruf dengan cara segera menyusun hurufhuruf yang diterimanya. Para mahasiswa berupaya mendampingi dan memandu siswa TK yang mengalami kesulitan menemukan huruf yang tepat untuk menyusun frasa yang diminta oleh kakak mahasiswa.

Jika sebagian besar siswa masih menemui kesulitan untuk menyusun huruf-huruf menjadi frasa, maka mahasiswa akan menayangkan ulang poster yang bertuliskan "anak bijak hidup hemat" dan mengajak para siswa TK untuk membacanya lagi. Akhirnya semua siswa TK merasa senang dan lega karena berhasil menyusun frasa yang diminta.

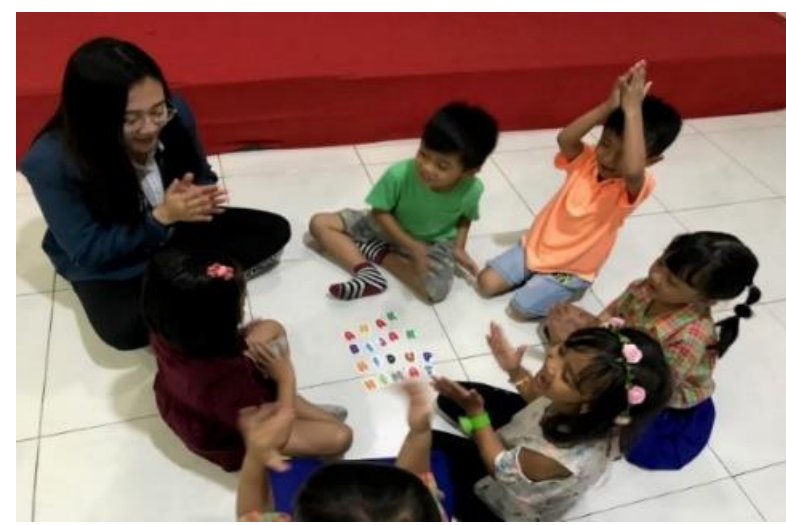

Gambar 7. Puzzle Huruf "Hidup Hemat"

\section{Permainan Puzzle Gambar}

Kegiatan menebak merupakan aktivitas yang menyenangkan bagi anak kecil. Kegiatan menebak menstimulir daya pikir siswa TK untuk menemukan jawaban atas tantangan yang diberikan kepadanya. Permainan puzzle gambar menstimulir daya pikir anak untuk merangkai potongan-potongan gambar menjadi gambar utuh yang tepat. 
Kegiatan Abdimas dengan tema "Hidup Hemat" mengajak para siswa TK untuk menyusun gambar salah satu aktivitas hidup hemat, yaitu 'membantu ibu'. Gambar 'membantu ibu' dicetak pada kertas manila putih berukuran kwarto. Kemudian satu lembar kertas di potong menjadi enam bagian dengan ukuran sama besar. Potongan kertas tersebut diacak, kemudian diberikan kepada setiap siswa TK atau sekelompok siswa TK yang beranggotakan dua atau tiga anak.

Setelah semua siswa diberi aba-aba untuk memulai menyusun potongan puzzle gambar, maka para siswa TK berusaha memasang potonganpotongan gambar menjadi gambar utuh yang tepat. Siswa atau kelompok siswa yang selesai lebih awal akan diberi apresiasi berupa snack.

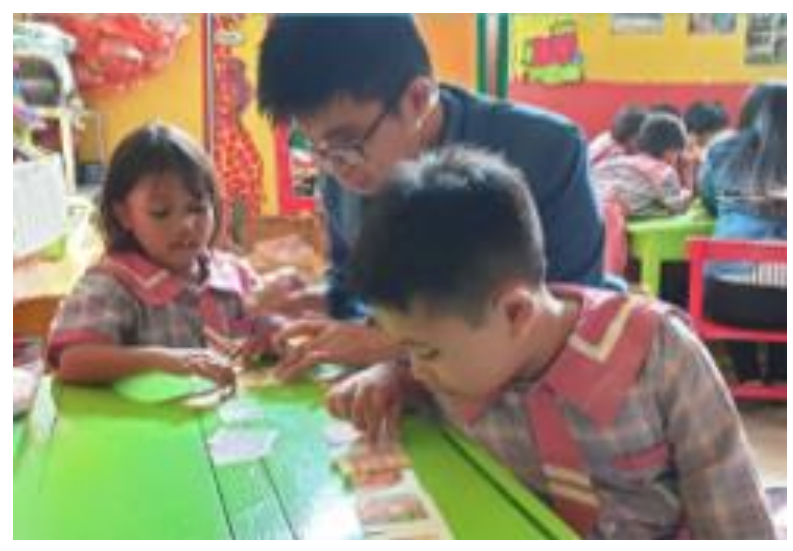

Gambar 8. Puzzle Gambar "Hidup Hemat"

Hasil isian angket para guru Taman-Kanakkanak, rata-rata menyatakan setuju bahwa Permainan Puzzle Huruf dan Puzzle gambar Hidup Hemat menyenangkan dan membantu daya ingat para siswa Taman Kanak-kanak untuk untuk mengingat bahwa hidup hemat merupakan hal yang baik.

\section{Mewarnai Gambar "Hidup Hemat"}

Salah satu aktivitas yang umum digemari para siswa TK, yaitu mewarnai gambar. Melalui aktivitas mewarnai, anak-anak dapat menyalurkan bakat seninya. Selain itu, kegiatan mewarnai memberikan perasaan rileks bagi anak-anak, sehingga anak-anak tidak merasakan tekanan dalam belajar.

Pesan Hidup Hemat dititipkan melalui gambar-gambar yang tertera dalam buku mewarnai. Misal, menggunakan air secukupnya saat mandi, membeli jika perlu, membantu ibu, dan gambar yang memeragakan praktik hidup hemat.

Pada saat mewarnai, para siswa TK diberi kebebasan memilih gambar yang ingin diwarnai. Pilihan warna juga terserah pada pilihan setiap siswa TK. Sementara siswa TK mewarnai, para mahasiswa berupaya membangun komunikasi dengan menanyakan mengapa adik memilih mewarnai gambar ini? Setelah siswa TK menjawab, sang mahasiswa akan merespon dengan pujian untuk memberi semangat kepada para siswa TK untuk mempraktikkan hidup hemat, seperti yang ada pada gambar yang sedang diwarnai.

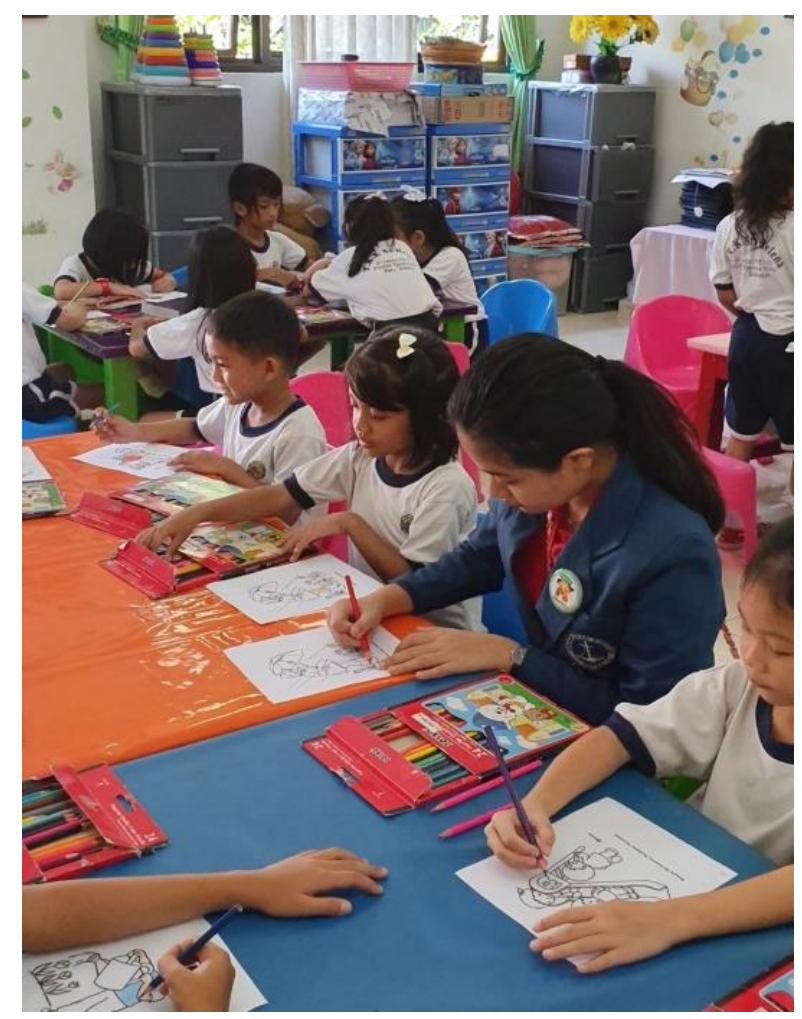

Gambar 9. Mewarnai "Hidup Hemat”

Hasil isian angket para guru Taman-Kanakkanak, rata-rata menyatakan setuju bahwa aktivitas mewarnai gambar-gambar praktik Hidup Hemat disenangi para siswa Taman Kanak-kanak dan mendorong para siswa Taman Kanak-kanak untuk bijak membelanjakan uang sakunya.

\section{KESIMPULAN}

Secara keseluruhan aktivitas, para guru Taman Kanak-kanak setuju bahwa aktivitas Pengabdian Masyarakat yang dilakukan mampu menumbuhkan kesadaran pada para siswa untuk mempraktikkan hidup hemat dengan memprioritaskan kebutuhan dan mengendalikan keinginan.

\section{REKOMEDASI}

Para guru Taman Kanak-kanak merekomendasikan untuk melanjutkan kegiatan Abdimas, baik dalam bentuk pengajaran yang ditunjang dengan media ajar yang menarik, panggung boneka, yang disertai dengan aktivitas permainan: kartu kembar, kartu domino, puzzle gambar, puzzle huruf, mewarnai gambar dengan tema yang mendidik dengan menambah variasi media ajar dan bentuk permainan menarik yang digunakan. 


\section{UCAPAN TERIMA KASIH}

Ucapan terima kasih disampaikan kepada seluruh mahasiswa peserta program Pengabdian Masyarakat matakuliah Keuangan Personal pada semester Genap 2018/2019 yang telah bekerja keras untuk mengedukasi para siswa TK dan Bunda TK di Surabaya dengan memanfaatkan secara optimal media ajar yang dibuat dan yang tersedia. Ucapan terima kasih juga disampaikan kepada para Kepala Sekolah TK. Kyai Ibrahim II, TK. Bina Nurani, TK. Yasporbi, TK. Yalista, TK. Kr. Eleos, TK. St. Caecilia, TK. Karya Widya, TK. Baptis pengharapan, TK. Kartini - Jl. Kutisari, TK. Bethel Sulung, TK. St. Helena, TK. Kartini - Jl. Genteng, TK. Mawar, TK. Hati Bunda, TK. Rainbow Kiddy, TK. Sekar Melati yang telah memberi kesempatan kepada para mahasiswa Program Manajemen Keuangan Program Studi Manajemen Fakultas Bisnis dan Ekonomi Universitas Kristen Petra untuk melakukan edukasi Hidup Hemat kepada para siswa TK.

\section{DAFTAR PUSTAKA}

Beaty, J. J. (2015). Observasi Perkembangan Anak Usia Dini (Ketujuh ed.). Jakarta: Kencana.

Boediono, L. (2019, September 11). Akses pada Pendidikan Anak Usia Dini yang Bermutu Penting untuk Pengembangan Modal Manusia yang Berkelanjutan. Dipetik September 12, 2019, dari World Bank: https://www.worldbank.org

Cermati.com. (2016, Januari 21). Ajarkan Anak Hidup Hemat, Lakukan Cara Jitu Ini. Dipetik Pebruari 19, 2019, dari Cermati.com: www.cermati.com

Dahana, R. P. (2015). Ekonomi Cukup. Jakarta: Kompas.

Fardana, N. A. (2017). Pengembangan Anak Usia Dini. In H. Indrijati, Psikologi Perkembangan \& Pendidikan Anak Usia Dini: Sebuah Bunga Rampai (pp. 160-164). Kencana: Jakarta.

Holloway, C. D. (2002). Metode-metode Riset Kualitatif dalam Public Relation \& Marketing Communications. (C. Wiratama, Trans.) Yogyakarta: Bentang.

Hurlock, E. B. (2017). Psikologi Perkembangan: Suatu Pendekatan Sepanjang Rentang Kehidupan. Jakarta: Erlangga.

Lewis, B. A. (2004). Character Building untuk Remaja. Batam: Karisma Publishing Group.

Tedjasaputra, M. S. (2001). Bermain, Mainan dan Permainan untuk Pendidikan Usia Dini. Jakarta: Grasindo.

Widayat, I. W. (2017). Perkembangan Emosi Anak. In H. Indrijati, Psikologi Perkembangan \& Pendidikan Anak Usia Dini: Sebuah Bunga Rampai (pp. 226-236). Jakarta: Kencana. 